\title{
ANALYSIS ON WHY LOW LEARNING OUTCOME OF MATHEMATICS AND SCIENCE IN ELEMENTARY SCHOOL AT BIMA DISTRICT
}

\author{
Mariamah Mariamah $^{1 *}$, I Wayan Suastra ${ }^{2}$, and Ida Bagus Aryana ${ }^{3}$ \\ ${ }^{1}$ Mathematics Education Study Program, STKIP Taman Siswa Bima, NTB, Indonesia \\ ${ }^{2,3}$ Magister of Science Education Study Program, Universitas Pendidikan Ganesha, Bali, Indonesia \\ *Email: mariamahmariamah85@yahoo.co.id
}

Accepted: January 18, 2022. Approved: January 19, 2022. Published: January 21, 2022

\begin{abstract}
Mathematics and science are two fundamental subjects for students to master to solve problems in everyday life. The reality shows that the learning outcomes of Mathematics and Science are still quite lacking. This study aims to analyze the low learning outcomes of Mathematics and Science in elementary schoole at Bima District West Nusa Tenggara, Indonesia. This research is a qualitative descriptive study with the research subjects being upper-class students' determination of research subjects by purposive sampling (based on research objectives). The instrument used to collect data is in the form of interview and documentation guidelines. The data were analyzed using the classical completeness formula to determine how many students completed and who did not complete. The results showed that the classical mastery for mathematics students at SDN Talabiu was in the deficient category (interval 120 ), with a mastery percentage of $13.51 \%$, while the science learning outcomes for upper-class students were in the less category (interval 21-40). with a percentage of 39\%. The low learning outcomes of Mathematics and Science are caused by two factors, namely students' internal factors and external factors. Internal factors related to psychology and physiology. External factors are influenced by family, school, and community conditions. The aspects of teachers and infrastructure strongly influence relationships with schools. Solutions have taken from low learning achievement caused by external factors (schools) by improving adequate infrastructure facilities and increasing teacher competencies, including educational, professional social, and personal competencies.
\end{abstract}

Keyword: Learning Outcomes, Mathematics, Science, Elementary School

\section{INTRODUCTION}

Mathematics and science are two subjects taught at the starting level packaged in theme-based Mathematics. Science is often considered a subject closely related to everyday life and is indispensable for learning. Science learning in elementary schools aims to develop knowledge and understand concepts that are useful for solving problems in everyday life. Science learning in elementary schools is also expected to provide direct learning experiences to form scientific attitudes science process skills, grow rational attitudes and think critically. Likewise, learning Mathematics in elementary schools has a goal such that students can solve problems in everyday life.

Science learning is integrated learning with other knowledge. Science learning in elementary schools is related to the scientific concept of the natural environment. The Learning Natural Sciences (IPA) is connected to systematically finding out about nature [1]. Science learning cannot be done by rote memorization or passively listening to the teacher explain the concept, but students themselves must learn through experimentation, observation, and experimentation [2]. Teachers must be able to facilitate students to understand the natural surroundings. Science learning is expected to be one of the steps to understand the natural surroundings well. As the development of the mindset of students, the related subjects are Natural Sciences (IPA) [3]. The values in science learning are expected to be applied in students' lives. Science learning is expected to be a vehicle for students to learn about themselves and their natural surroundings and further development in everyday life [4].

The purpose of the 2013 curriculum of science learning based on content standards for elementary school students is to provide meaningful learning experiences by developing various attitudes, knowledge, and skills. In the Regulation of the Minister of Education and Culture Number 64 of 2013 science learning is expected so that students have the following competencies: (1) demonstrate behavior of faith in God Almighty One as a result of observing science objects, (2) showing scientific attitudes: curiosity, honesty, logical, critical, disciplined, and responsible through science, (3) asking questions: what, why, and how about the natural surroundings, (4) observing natural science objects using the five senses and simple tools, (5) presenting data from observations of the natural surroundings in the form of tables or graphs, (6) making conclusions and reporting the results of observations of the natural surroundings orally and in writing in simple terms, (7) explains the concepts and principles of science [5]. From the objectives and competencies to be achieved, based on empirical data in the field, it shows that the students' abilities from the results of learning Mathematics and Science in 
elementary school (cognitive, affective and psychomotor aspects) have not met expectations. This is based on the results of previous studies, fifth grade students of SD Negeri 12/30 Kanaungan Pangkep Regency consider that science is a difficult subject and student learning outcomes are low [6]. Students' science learning outcomes are still lacking $[7,8]$. From the problems described above, it is not much different from the conditions that occurred at SDN Talabiu that there are still students who have not maximized science learning outcomes

The studies carried out are mostly researched by applying various models, methods, and media to overcome the existing problems. Implementation of Local WisdomBased Natural Science Learning Model to Improve Student Creativity and Learning Outcomes. Application of project-based learning model to improve creativity and science learning outcomes in 5th-grade elementary school students. There have not been many studies that analyze why learning outcomes in mathematics and science are low. So that this research is deemed necessary to find out how the mathematics and science learning outcomes at SDN Talabiu, what factors cause the low mathematics and science learning outcomes of students, and what is the right solution to overcome the existing problems.

\section{RESEARCH METHODS}

descriptive study quantitative with the research subjects being 37 high school students. The instruments used to collect data are interview guides and documentation. The data were analyzed by using the classical completeness formula to find out how many percent of students completed and those who did not. While the analysis of data from interviews using qualitative analysis. The following is the classical completeness formula.

After the student scores are analyzed using the classical completeness formula, then they will be consulted again according to the following intervals to find out the categories of students' mathematics and science learning outcomes.

Table 1. Category of student learning outcomes

\begin{tabular}{cc}
\hline Interval & Category \\
\hline $81-100$ & Very high \\
$61-80$ & high \\
$41-60$ & Enough \\
$21-40$ & Less \\
$1-20$ & Very low \\
\hline
\end{tabular}

\section{RESULTS AND DISCUSSION}

Results The results of the study show that the mathematics and science learning outcomes of upper class students are still in the poor category. The following data have been analyzed:
Table 2. Percentage of classical completeness Mathematics

\begin{tabular}{cc}
\hline Grade & completeness classical \\
\hline IV & $5.31 \%$ \\
V & $4.12 \%$ \\
VI & $4.8 \%$ \\
TOTAL & $13.51 \%$ \\
\hline
\end{tabular}

From table 2 above it can be seen that classical completeness for class IV by $5.31 \%$, class V by $4.12 \%$, for class VI by $4.12 \%$

Table 3. Percentage of classical completeness Science Learning

\begin{tabular}{cc}
\hline Grade & Classical completeness \\
\hline IV & $10.5 \%$ \\
V & $9.7 \%$ \\
VI & $18.8 \%$ \\
TOTAL & $39 \%$
\end{tabular}

From table 3 above it can be seen that classical completeness for class IV is $10.5 \%$, class $\mathrm{V}$ is $9,7 \%$, for class VI it is $18.8 \%$. The following is the difference in the percentage of classical completeness data for mathematics and science

Table 4. The difference in the percentage of classical completeness in Mathematics and

\begin{tabular}{ccc}
\hline Class & \multicolumn{2}{c}{ Classical } \\
& Mathematics & Science \\
\hline IV, V, VI & $13,51 \%$ & $39 \%$ \\
\hline
\end{tabular}

From the data in table four above, if consulted with table one, it can be it is known that outcomes are in the very low category (interval 1-20), namely with a completeness percentage of $13.51 \%$, while for the science learning outcomes of upper class students are in the less category (interval 21-40) with a percentage of $39 \%$. This data is in line with data released by TIMSS (Trends in International Mathematics and Science Study) and PISA (Program for International Student Assessment). Based on data released Culture in 2016 in relation to the science ranking data of Indonesian students, TIMSS has measured the achievement of Indonesian students in 1999, based on an international standard score of 500, stating that the average score of achievement scores obtained by Indonesian students is at the level or ranked 32 out of 38 countries with a score of 435 . In 2003 it got a score of 420 which was ranked 37 out of 46 countries. In 2007 it got a score of 427 with a ranking of 35 out of 
49 countries. In 2011 it got a score of 406 with a rank of 40 out of 59 countries and in 2015 it was ranked 45 out of 48 countries with a score of 397 . From the data presented by TIMSS, it shows that the achievement of Indonesian students in the field of Science is still in category.

Furthermore, the data presented by PISA (Program for International Student Assessment) starting in 2000 got a score of 393 with a rank of 38 out of 41 countries, in 2003 it got a score of 395 with a rank of 38 out of 40 countries, in 2006 it got a score of 393 with a rank of 50 out of 57 countries, and in 2009 obtained a score of 383 with a rating of 60 out of 65 countries. All scores are below the international average score of 500

OECD in 2016 conveying about the scientific achievements of Indonesian students by getting 383 scores and ranking 64 out of 65 countries, while the latest results in 2015 Indonesia was ranked 62 out of 70 countries by getting 403 score. Various survey data from TIMSS, PISA and OECD show that the achievements of Indonesian students in the field of science are in the very low category or low international benchmark.

The low mathematics and science learning outcomes of students in elementary schools can be seen through various research results that have been carried out by researchers. The following is an illustration of some research results that represent the relationship with real data on student learning outcomes in elementary school. Science Learning in elementary schools still finds various kinds of problems, one of which is the low science students in elementary schools [9]. students' scientific thinking ability is still weak [10]. results of students' science learning in elementary schools are still having problems [11]. The result of learning science in elementary school is still low [12]. In addition, Mathematics also experienced the same thing, namely the low learning outcomes of students and there were still many students who did not like mathematics. There Are still many students who are afraid of mathematics and consider mathematics to be a difficult subject [13]. Various previous research results show that students' mathematics learning outcomes are still less than optimal [14-19].

From the data on the low learning outcomes of mathematics and science in elementary schools, it is known that there are various factors that cause this to happen. According to Baharudin and Wahyuni, the factors that influence learning outcomes are divided into internal factors and external factors [20].

Internal factors are driving factors that come from within students such as physiological factors which include physical factors, health factors, physical disability factors and psychological factors including motivation, interests, talents, habits and concentration. factors can indeed affect science learning outcomes. Motivation Affects the Learning Outcomes of elementary school students [21].
External factors are aspects that come from outside the individual that affect student learning outcomes such as: 1) family factors which include factors from the educational background of parents, the way parents educate, relations between family members, and the atmosphere of the house. 2) school factors that influence learning include teaching methods, learning methods and facilities and infrastructure. the last 3 ) community factors. [22]

Relation to school factors such as teaching methods, this is strongly influenced by human resources, namely teachers as actors in learning practices in schools. The success of students in learning is strongly influenced by the ability of teachers to teach. One Of the causes of students' science learning outcomes is caused by the learning carried out by the teacher who is memorizing and shallow without applying various techniques of learning [23,24].

\section{Solution to the Problem of Low Science Learning Outcomes in SD}

One Of the strategic steps in overcoming problems in science learning is to improve the quality of learning which is carried out through various activities as follows [25].

a. Improving professionalism of science teachers

Teachers have a very big role in achieving the success of the learning that is carried out. Teachers are required to be able to make students active, manage the learning environment well, and be able to guide students in learning [26].teachers Professional are teachers who have 4 competencies, namely pedagogic, personality, professional and social. Competencies to be improved and continue to be developed so that science teachers become professional. Increased competence can be through activities such as: 1) continuing education to a higher level, 2) training, 3) upgrading, 4) seminars, 5) discussions, or 6) fostering relationships between teacher-printing institutions and schools

. are required to be able to master various learning models, so that learning is carried out effectively and fun for students. This is evidenced by the results of various studies that have conducted experiments. In Learning science in schools, teachers are required to use media [27]. Science learning cannot be separated from the use of media that can help students understand the material being taught, the results of other studies recommend that teachers in science learning can take advantage of various media that match the material being taught. [28-30].

In addition to the use of various media, teachers are also required to master teaching methods. There Are various recommended learning models to be applied in science learning in 
elementary schools such as CTL, inquiry, problembased learning, and cooperative learning [31]. Projectbased learning, improving process skills of students who receive problem-based learning (PBM) is better than students who receive non-PB learning [32]. In addition, teachers must also be creative in creating atmosphere pleasant learningLearning is not only carried out in the classroom but can also be carried out outside the classroom. Outdoor learning can provide students with hands-on learning experiences, but it also provides them with many opportunities to interact with their peers and their environment [33]. b. Fulfillment of adequate

facilities and infrastructure Learning facilities and infrastructure greatly affect success in learning. If the learning facilities are adequate, it will be very helpful for teachers and students in learning. On the other hand, if the facilities and infrastructure are inadequate, it will hinder the learning that is carried out. Analysis of the low science learning outcomes that have been described above, can be summarized in the following figure:

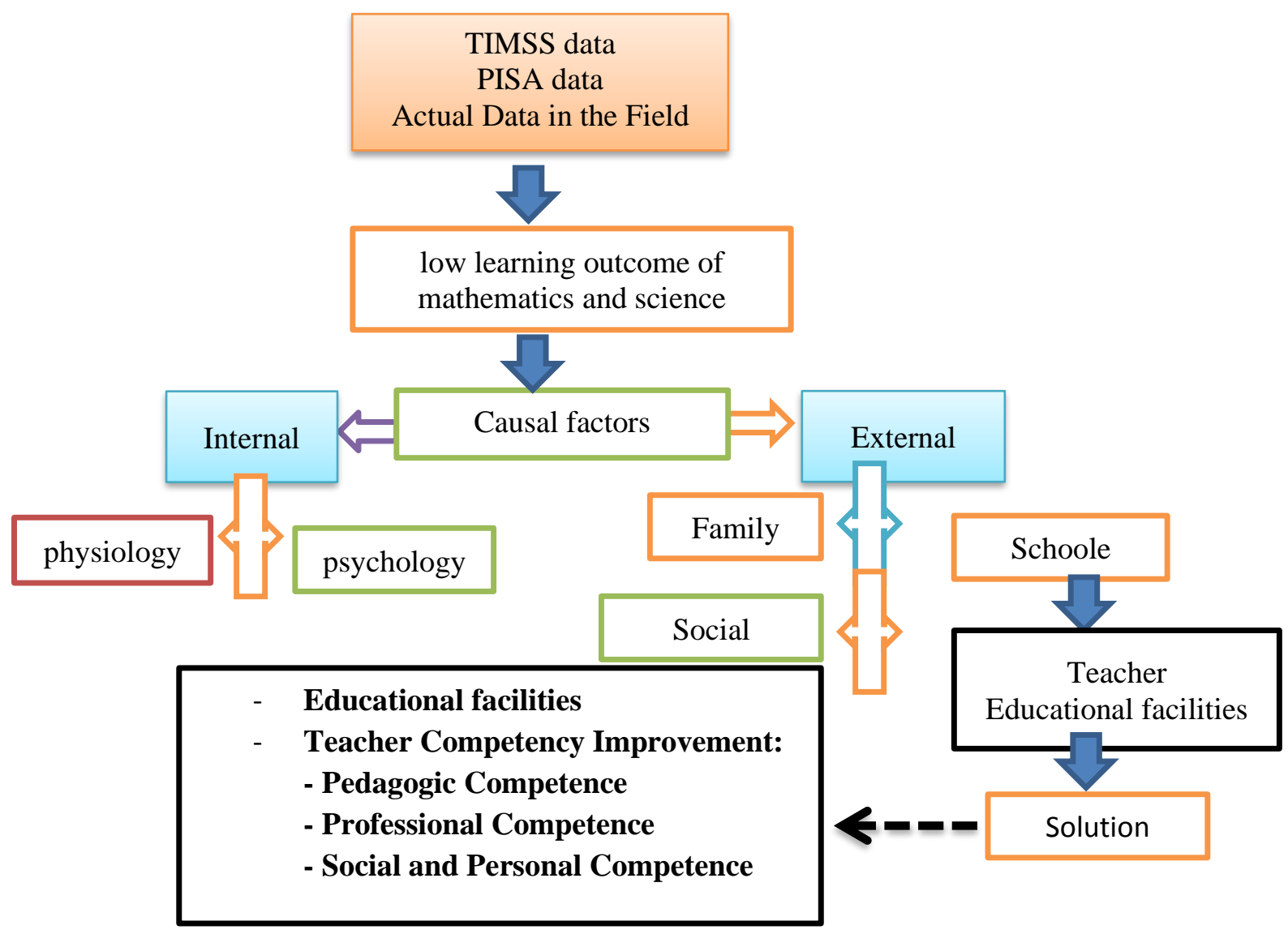

Figure 1. Analysis Framework

\section{CONCLUSION}

Learning outcomes mathematics SDN Talabiu students are in the deficient category (interval 1-20), with a completeness percentage of $13.51 \%$, while the science learning outcomes of upper-class students are in the less category (interval 21-40) with a percentage of $39 \%$. From the description above, it can be concluded that students' low mathematics and science learning outcomes in elementary schools are caused by two factors, namely students' internal and external factors. Internal factors were related to psychology and physiology. External factors are influenced by family, school, and community conditions. The factors of teachers and infrastructure strongly influence relationships with schools. The solution is taken from the low learning achievement caused by external factors (schools) by improving adequate infrastructure facilities and increasing teacher competencies, including pedagogical, professional, and social and personal competencies.

\section{REFERENCES}

[1] Kurniasih, D. (2018). Peningkatan minat dan hasil belajar IPA melalui model pembelajaran think 
J. Pijar MIPA, Vol. 17 No.1, January 2022: 100-105

DOI: 10.29303/jpm.v17i1.3227

pair share. Natural: Jurnal Ilmiah Pendidikan IPA, 5(1), 7-11.

[2] Sulthon, S. (2016). Pembelajaran IPA yang Efektif dan Menyenangkan bagi Siswa MI. Elementary, 4(1).

[3] Astalini, A., Kurniawan, D. A., \& Putri, A. D. (2018). Identifikasi sikap implikasi sosial dari IPA, ketertarikan menambah waktu belajar IPA, dan ketertarikan berkarir dibidang IPA siswa SMP se-kabupaten Muaro Jambi. Tarbiyah: Jurnal Ilmiah Kependidikan, 7(2).

[4] Surahman, S., Paudi, R. I., \& Tureni, D. (2015). Meningkatkan Hasil Belajar Siswa Dalam Pembelajaran IPA Pokok Bahasan Makhluk Hidup Dan Proses Kehidupan Melalui Media Gambar Kontekstual Pada Siswa Kelas II SD Alkhairaat Towera. Jurnal Kreatif Online, 3(4).

[5] Nugraha, A. J., Suyitno, H., \& Susilaningsih, E. (2017). Analisis kemampuan berpikir kritis ditinjau dari keterampilan proses sains dan motivasi belajar melalui model pbl. Journal of Primary Education, 6(1), 35-43..

[6] Alamsyah, N. (2016). Penerapan pendekatan saintifik untuk meningkatkan kreativitas dan hasil belajar siswa dalam mata pelajaran IPA. $J P$ (Jurnal Pendidikan): Teori dan Praktik, 1(1), 82-96.

[7] Pamungkas, A., Subali, B., \& Linuwih, S. (2017). Implementasi model pembelajaran IPA berbasis kearifan lokal untuk meningkatkan kreativitas dan hasil belajar siswa. Jurnal Inovasi Pendidikan IPA, 3(2), 118-127..

[8] Nugraha, A. R., Kristin, F., \& Anugraheni, I. (2018). Penerapan Model Pembelajaran Project Based Learning (Pjbl) Untuk Meningkatkan Kreativitas Dan Hasil Belajar Ipa Pada Siswa Kelas 5 Sd. KALAM CENDEKIA PGSD KEBUMEN, 6(4.1).

[9] Fauzia, N. L. U., \& Kelana, J. B. (2021). Natural Science Problem Solving in Elementary School Students Using the Project Based Learning (PjBL) Model. Jurnal Ilmiah Sekolah Dasar, 4(4), 596-603.

[10] Kenedi, A. K., Chandra, R., \& Fitria, Y. (2019, December). Problem based learning: a way to improve critical thinking ability of elementary school students on science learning. In Journal of Physics: Conference Series (Vol. 1424, No. 1, p. 012037). IOP Publishing.

[11] Khairani, S., Suyanti, R. D., \& Saragi, D. (2020). The Influence of Problem Based Learning (PBL) Model Collaborative and Learning Motivation Based on Students' Critical Thinking Ability Science Subjects in Class V State Elementary School 105390 Island Image. Budapest International Research and Critics in Linguistics
ISSN 1907-1744 (Print)

ISSN 2460-1500 (Online)

and Education (BirLE) Journal,3(3), 15811590.

[12] Faridah, F., Salahudin, S., Mariamah, M., \& Ajwar, M. (2021). Students' learning creativity by the implementation of contextual-based learning in the subject of natural science. Jurnal Pijar Mipa, 16(5), 659-663.

[13] Mariamah, M., Ratnah, R., Katimah, H., Rahman, A., \& Haris, A. (2021, June). Analysis of Students' Perceptions of Mathematics Subjects: Case studies in Elementary Schools. In Journal of Physics: Conference Series (Vol. 1933, No. 1, p. 012074). IOP Publishing.

[14] Saputra, D. S., Yuliati, Y., \& Rachmadtullah, R. (2019, November). Use of ladder snake media in improving student learning outcomes in mathematics learning in elementary school. In Journal of physics: conference series (Vol. 1363, No. 1, p. 012058). IOP Publishing.

[15] Mulyanto, H., Gunarhadi, G., \& Indriayu, M. (2018). The effect of problem based learning model on student mathematics learning outcomes viewed from critical thinking skills. International Journal of Educational Research Review, 3(2), 37-45..

[16] Salam, M., Ibrahim, N., \& Sukardjo, M. (2019). Effects of Instructional Models and Spatial Intelligence on the Mathematics Learning Outcomes after Controlling for Students' Initial Competency. International Journal of Instruction, 12(3), 699-716.

[17] Sumantri, M. S., \& Satriani, R. (2016). The Effect of Formative Testing and Self-Directed Learning on Mathematics Learning Outcomes. International Electronic Journal of Elementary Education, 8(3), 507-524.

[18] Ardila, A., \& Hartanto, S. (2017). Faktor yang mempengaruhi rendahnya hasil belajar matematika siswa mts iskandar muda batam. PYTHAGORAS: Journal of the Mathematics Education Study Program, 6(2).

[19] M. Mariamah, M. Muslim, G. Gunawan, A. Hidayat, and Suratman, "The Effectiveness of Think Pair Share (TPS) Integrated ProblemSolving Learning of Students' Mathematic Ability," J. Phys. Conf. Ser.,1933 (1)

[20] Kristin, F. (2016). Analisis model pembelajaran discovery learning dalam meningkatkan hasil belajar siswa SD. Jurnal Pendidikan Dasar Perkhasa: Jurnal Penelitian Pendidikan Dasar, 2(1), 90-98.

[21] Nugroho, G. (2020). Analisis Motivasi Belajar Siswa Pada Pembelajaran IPA di SDN16/II Sepunggur. Integrated Science Education Journal, 1(2), 65-69. 
[22] Jufrida, J., Basuki, F. R., Pangestu, M. D., \& Prasetya, N. A. D. (2019). Analisis Faktor yang Mempengaruhi Hasil Belajar IPA dan Literasi Sains di SMP Negeri 1 Muaro Jambi. Edufisika: Jurnal Pendidikan Fisika, 4(02), 31-38.

[23] Kurniawati, D., Muhlis, M., \& Makhrus, M. (2020). Validitas Multimedia Interaktif Berbasis Indikator Penguasaan Konsep dan Kemampuan Berpikir Kreatif Pada Materi Kemagnetan. Jurnal Pijar Mipa, 15(5), 528532.

[24] E. Satria and W. Sopandi, (2011).Applying RADEC model in science learning to promoting students' critical thinking in elementary school. J. Phys. Conf. Ser., vol. 1321, no. 3, 2019, doi: 10.1088/1742-6596/1321/3/032102.

[25] Sari, M. (2013). Problematika pembelajaran sains ditinjau dari aspek guru. $\mathrm{Al}-\mathrm{Ta}$ lim Journal, 20(1), 346-356.

[26] A. Gecer and R. Ozel, "Elementary Science and Technology Teachers' Views on Problems Encountered in the Instructional Process," Educ. Sci. Theory Pract., vol. 12, no. 3, pp. 2256-2261, 2012.

[27] Portanata, L., Lisa, Y., \& Awang, I. S. (2017). Analisis pemanfaatan media pembelajaran IPA SD. JURNAL PENDIDIKAN DASAR PERKHASA: Jurnal Penelitian Pendidikan Dasar, 3(1), 337-348.

[28] Azimi, A., Rusilowati, A., \& Sulhadi, S. (2017). Pengembangan Media Pembelajaran IPA Berbasis Literasi Sains untuk Siswa Sekolah Dasar. PSEJ (Pancasakti Science Education Journal), 2(2), 145-157.

[29] Syawaludin, A., Gunarhadi, G., \& Rintayati, P. (2019). Enhancing elementary school students' abstract reasoning in science learning through augmented reality-based interactive multimedia. Jurnal Pendidi

[30] Sun, K. T., Lin, Y. C., \& Yu, C. J. (2008). A study on learning effect among different learning styles in a Web-based lab of science for elementary school students. Computers \& Education, 50(4), 1411-1422.

[31] Glynn, S. M., \& Linda, K. (2015). Winter. 2004."Contextual Teaching and Learning of Science in Elementary Schools.". Journal of Elementary Science Education, 16(2), 51-63.

[32] Yuliati, Y. (2016). Peningkatan keterampilan proses sains siswa sekolah dasar melalui model pembelajaran berbasis masalah. Jurnal Cakrawala Pendas, 2(2), 266390.
[33] Huang, Y. M., Lin, Y. T., \& Cheng, S. C. (2010). Effectiveness of a mobile plant learning system in a science curriculum in Taiwanese elementary education. Computers \& Education, 54(1), 4758. 